DOI: $10.14451 / 2.156 .33$

\title{
АКТУАЛЬНЫЕ ВОПРОСЫ ПРАКТИКИ РАССМОТРЕНИЯ АРБИТРАЖНЫМИ СУДАМИ СПОРОВ ИЗ ДОГОВОРА СТРОИТЕЛЬНОГО ПОДРЯДА
}

\author{
(c) 2021 Скачкова Ольга Викторовна \\ кандидат юридических наук, доцент кафедры гражданского и арбитражного процесса \\ Самарский государственный экономический университет, Россия, Самара

\section{(c) 2021 Карапетян Аида Артаковна} \\ магистрант \\ Самарский государственный экономический университет, Россия, Самара
}

В данной статье на основе анализа гражданского законодательства и научной литературы было заключено, что договор строительного подряда представляет собой практически самый часто встречающийся гражданско-правовой договор. При этом его значение для гражданского оборота трудно переоценить, поскольку он охватывает широкий круг отношений непосредственно в сфере производства. В этой связи закономерно большое число судебных дел в пределах правоотношений данной области. В рамках исследования анализируется судебная практика в данной области. Вследствие чего отмечается, что взаимоотношения сторон изучаемого договора в действительности в большинстве случаев являются трудными и разнообразными, что обуславливает чрезвычайное многообразие судебных споров в этой области.

Ключевые слова: договор подряда, договор строительного подряда, спор, арбитражное судопроизводство.

Многообразие видов хозяйственноэкономических отношений существующих в современном мире обуславливает необходимость в большом наборе гражданско-правовых договоров их регулирующих*. Среди прочих договоров гражданско-правого характера, регламентирующих отношения в данной области значимую позицию получил подрядный, а особенно одна из его разновидностей - договор строительного подряда. В этой связи закономерно большое число судебных дел в пределах правоотношений данной области.

В действующей редакции Гражданского кодекса Российской Федерации (далее - ГК РФ)** законодателем дано легальное определение рассматриваемого гражданско-правого договора. Так, согласно положениям ст. 740 указанного нормативного акта в рамках рассматриваемого договора на сторону, именуемую подрядчиком, возлагается обязанность в определенный договором временной промежуток произвести строительство по указанию стороны, именуемой заказчиком, конкретного объекта или исполнить другие работы в области строительства. На сторону, именуемую заказчиком, в свою очередь, возлагаются обязанности по организации для стороны, именуемой подрядчиком, требуемой для исполнения работы обстановки, а также приему их итогов и выплате в пользу стороны, именуемой подрядчиком, конкретной денежной суммы.

Своеобразный предмет исследуемого договора, а также значительное количество возможных участников, крупные расходы в денежном эквиваленте, большой временной промежуток исполнения работы и прочие факторы становятся причиной того, что взаимоотношения сторон изучаемого договора в действительности в большинстве случаев являются трудными и разнообразными***. Следовательно, и судебные разбирательства, неминуемо образовывающиеся между сторонами рассматриваемого договора в

* Ланг П.П.Ценностное измерение правового регулирования // Вопросы экономики и права. 2018. № 121. С. 20-24; Ланг П. П. Особые производства в юрисдикционном процессе: деятельностное основание // Актуальные проблемы правоведения. 2019. № 4(64). С. 60-68.

** Гражданский кодекс Российской Федерации (часть вторая) от 26 января 1996 г. № 14-Ф3 // Собрание законодательства РФ. 29.01.1996 г. № 5. Ст. 410.

*** См.: Гринштейн А.И. К вопросу о содержании договора подряда по законодательству Российской Федерации // Эпомен. 2020. № 44. С. 93. 
процессе выполнения обязательств в данной области также чрезвычайно разнообразны.

На основе анализа судебной практики нами была разработана классификация распространенных судебных разбирательств по вопросам исследуемой области.

1. Первой категорией споров возникающих из исследуемых договоров, наиболее часто встречающихся в судебной практике, являются споры, образующиеся связи с нарушением условий, являющихся существенными для рассматриваемого договора.

Ранее нами было отмечено, что в с. 740 ГК РФ законодатель дал легальное определение рассматриваемому договору. Исходя из анализа данного определения, существенным условием исследуемого договора является срок. Значимость данного условия неоспорима, так как очевидно, что для стороны данного договора, именуемой заказчиком, важно исполнение работы не в принципе, а к конкретному времени. Для целей исследуемого договора обыкновенно выделяют две группы сроков, к первой причисляют время, когда началось осуществление работ, а ко второй время, когда они были закончены.

Неуказание данного условия, являющегося существенным, в тексте договора строительного подряда, а равно его определение ненадлежащим образом становится причиной признания исследуемого договора обладающим всеми признаками договора который не был заключен в соответствии с положениями ст. 432 ГК РФ.

В частности, стороне заказчика судом было отказано в исковых требованиях в отношении стороны подрядчика, по причине неуказания в тексте договора сроков в которые осуществление работ должно начаться и окончиться, поскольку данный договор в соответствии с гражданским законодательством обладает всеми признаками договора, который не был заключен*.

Длительность срока для целей исследуемого договора устанавливается по согласованию его сторон. В настоящее время действующим гражданским законодательством не предусмотрены особые правила, в соответствии с которыми устанавливались бы наименьший и предельный сроки, в которые необходимо исполнить работы, обозначенные в договоре.

При этом важно отметить, что установлен- ные гражданским законодательством правила оформления исследуемого существенного условия в тексте договора строительного подряда подразумевают, что сроки необходимо либо установить в качестве конкретных дат либо связать с определенным событием, которое в любом случае совершится. К примеру, в своем решении суд отметил, что одно из существенных условий исследуемого договора в его тексте звучит как: «через неделю после выплаты суммы аванса стороной заказчика в отношении стороны подрядчика».

По мнению суда, установление исследуемого существенного условия произошло в связи указанным событием, что противоречит положениям гражданского законодательства, а именно нет оснований полагать, что аванс будет уплачен неизбежно. По этой причин, ввиду отсутствия одного из существенных условий, договор был признан судом договором, который не был заключен ${ }^{* *}$.

2. Второй категорией распространенных судебных споров в исследуемой области являются разбирательства, сопряженные с неправильным осуществлением процесса приема итогов исполненных работ и пренебрежением правилами его фиксации.

Заметим, что значимым для правильной реализации указанного процесса является установление лиц, в компетенции которых его осуществление. В частности в ситуациях, когда к нему причастна сторонняя компания.

Вдобавок необходимо отметить, что немаловажным в данной ситуации является правильное составление документации. В частности неправомерным является оформление документации одной из сторон без участия другой стороны, поскольку в соответствии с гражданским законодательством обе стороны должны заверить своими подписями документацию.

В качестве примера рассмотрим следующую ситуацию. Субподрядчик оформил приемочную документацию самостоятельно и решением суда такие документы были признаны ненадлежащей доказательственной информацией, поскольку они были составлены без учета принятых в договоре правил, а именно генеральный подрядчик не был должным образом извещен о том, что начался процесс приема итогов работы

\footnotetext{
* Постановление Девятого арбитражного апелляционного суда от 25.05.2011 № 09АП-9402/2011 по делу № А40$25488 / 10-45-169$.

** Постановление ФАС Уральского округа от 15.11.2005 № Ф09-3716/05-С4 по делу № А60-9886/2005.
} 
и, находившийся там при этом, представитель сторонней компании не обладал необходимой компетенцией для реализации деятельности по приему итогов исполненных работ и контроля за оформлением документации*.

Исходя из изложенного, можно заключить, что для участия сторонней компании в указанных процессах требуется конкретно определить ее компетенцию и зафиксировать ее в тексте исследуемого договора. В противном случае заверение документации подписями ее представителей не несет правовых последствий.

Нередкими в практической деятельности являются ситуации несвоевременного приема исполненных работ со стороны заказчика. Так согласно положениям гражданского законодательства на указанную сторону исследуемого договора возложена обязанность по незамедлительному принятию итогов работ сразу после уведомления об их исполнении со стороны подрядчика.

Как нами было отмечено ранее, приемочная документация должна быть заверенная подписями всех сторон исследуемого договора. При этом анализ судебной практики показал, что в ситуациях, когда сообщение об исполнении работ со стороны подрядчика было направлено, а со стороны заказчика возложенная обязанность по принятию ее итогов исполнена не была, первый получает возможность оформить приемочную документацию без участия последних ***

Указанное особенно важно в связи с тем, что только наличие приемочной документации может свидетельствовать о том, что работы в рамках исследуемого договора были исполнены. Так судом не были удовлетворены требования направленные на взыскание со стороны заказчика долга за исполненные работы по причине непредставления приемочной документации. В своем решении суд отметил, что события, подтверждаемые в силу положений законодательства конкретными документами, нельзя обосновать другой доказательственной информацией, в частности заключением эксперта***.

3. Также к часто встречающимся в судебной практике спорам, вытекающим из договора подряда можно отнести разбирательства, сопря- женные с ненадлежащим исполнением возложенных на стороны исследуемого договора обязанностей.

Так согласно положениям гражданского законодательства в тексте исследуемого договора необходимо обозначить на какую из сторон возложена обязанность по предоставлению требуемых для осуществления деятельности документов технического характера, а также, в течение какого времени она должна быть исполнена. В ситуациях, когда данная обязанность должна была быть реализована стороной заказчика, но этого не последовало, в случае обращения в суд стороне заказчика отказывают в удовлетворении требований о взыскании со стороны подрядчика убытков величиной, требуемой для нейтрализации осуществленных стороной подрядчика ошибок.

Вдобавок, гражданское законодательство предусматривает обязанность стороны подрядчика выполнять свою деятельность строго согласно документации технического характеpa, в частности устанавливающей количество и содержание работ и иные обязательные для них условия, а также документации, устанавливающей необходимые денежные затраты на выполнение работ. В ситуациях, когда сторона подрядчика приступила к исполнению работ в рамках исследуемого договора, не имея соответствующей технической документации, сторона заказчика имеет право предъявить требования о возвращении сумм, переданных в виде предварительной оплатын头范.

Таким образом, в ситуациях, когда стороной заказчика не были реализованы возложенные исследуемым договором обязанности, противной стороне тоже не следует начинать исполнять свои обязанности.

Основной обязанностью, возложенной на подрядчика, является исполнение определенной работы. При этом она исполняется в соответствии с указаниями противной стороны, а именно согласно тому, что было прямо указано в заключенном договоре и иных сопутствующих ему документах. При этом важно, что подрядчик должен не просто исполнить свою основную обязанность, а исполнить ее высококачествен-

\footnotetext{
* Определение ВАС РФ от 06.07.2011 № ВАС-7913/11 по делу № А24-2273/2010.

** Постановление ФАС Московского округа от 02.09.2005 № КГ-А41/8168-05

**** Постановление ФАС Волго-Вятского округа от 14.07.2005 № А29-3689/2004-4э.

**** Постановление ФАС Московского округа от 25.08.2005 № КГ-А40/8115-05.
} 
но, руководствуясь стандартами в данной сфере, установленными государством, а также утвержденными нормами и правилами в области строительства. В ситуациях, когда стороной подрядчика указанная обязанность не была выполнена, что доказывается экспертным заключением, сторона заказчика имеет право на свое усмотрение предъявить одно из следующих требований: по ликвидации недочетов без дополнительной оплаты в разумный временной промежуток; по компенсации понесенных денежных трат в результате самостоятельной ликвидации заказчиком недочетов, в ситуациях, когда он наделен таким правом в соответствии с договором. В случае, если обнаруженные недочеты не были ликвидированы, сторона заказчика наделена правом отказа выполнения обязательств по договору, а также требования компенсации понесенных денежных потерь *.

4. Еще одной категорией споров вытекающих из договоров строительного подряда, рассматриваемых арбитражными судами, достаточно часто встречающихся в судебной практике, являются разбирательства компаний, занимающихся строительством, и налоговых органов по проблемам в сфере финансов.

Так наиболее часто встречающиеся разбирательства рассматриваемой категории образуются в процессе использования вычетов НДС либо возмещении НДС. Так проведенный анализ судебной практики показал, что нередко организации, занимающиеся строительством, получают от налоговых органов неправомерные отказы в этой сфере. При этом важно отметить, что чаще всего споры разрешаются в пользу строительных организаций.

На сегодняшний день получило широкое распространение создание различных строительных объектов для личных потребностей и своими усилиями. В этой связи образуются сложности с определением правил, по которым необходимо осуществлять процесс налогообложения относительно строительных организаций, занимающихся указанной деятельностью**. В частности, возникает вопрос о том, когда возможен вычет налогов.

Рассмотрим следующий пример. В своем решении суд указал, что компания занимающаяся строительством, в данной ситуации одновременно является и стороной заказчика и стороной подрядчика по договору и потому, в соответствии с положениями налогового законодательства обладает правом применения налогового вычета только после завершения строительных работ ${ }^{* * *}$.

Таким образом, на основе проведенного анализа судебной практики по разрешению спорных вопросов в исследуемой области можно сделать вывод, что чаще всего они образуются из-за неправильного оформления текста договора.

\section{Библиографический список}

1. Ланг П. П. Ценностное измерение правового регулирования // Вопросы экономики и права. 2018. № 121. С. $20-24$.

2. Ланг П.П. Особые производства в юрисдикционном процессе: деятельностное основание // Актуальные проблемы правоведения. 2019. № 4(64). С. 60-68.

3. Гражданский кодекс Российской Федерации (часть вторая) от 26 января 1996 г. № 14-Ф3 // Собрание законодательства РФ. 29.01.1996 г. № 5. Ст. 410.

4. Гринштейн А.И. К вопросу о содержании договора подряда по законодательству Российской Федерации // Эпомен. 2020. № 44. С. 92-98.

5. Постановление Девятого арбитражного апелляционного суда от 25.05.2011 № 09АП-9402/2011 по делу № A40-25488/10-45-169.

6. Постановление ФАС Уральского округа от 15.11.2005 № Ф09-3716/05-С4 по делу № А60-9886/2005.

7. Определение ВАС РФ от 06.07.2011 № ВАС-7913/11 по делу № А24-2273/2010.

\footnotetext{
* См.: Абрамцева Е.Л.Договор подряда в гражданском праве России: дисс. ...канд. юрид. наук. Волгоград.2005. C. 52 .

** Ланг П.П.Правила тонкой капитализации Налогового кодекса Российской Федерации // Юриспруденция в современном мире: проблемы и перспективы: сборник научных трудов подготовленный по материалам общероссийской научно-практической конференции, Тамбов, 15 января 2015 года.- Тамбов: Тамбовский филиал Негосударственного образовательного частного учреждения высшего профессионального образования «Академический правовой институт», 2015. С. 130-133.

**** Постановление ФАС Центрального округа от 23.05.2008 по делу № А23-557/07Г-19-70.
} 
8. Постановление ФАС Московского округа от 02.09.2005 № КГ-А41/8168-05.

9. Постановление ФАС Волго-Вятского округа от 14.07.2005 № А29-3689/2004-4э.

10. Постановление ФАС Московского округа от 25.08.2005 № КГ-А40/8115-05.

11. Абрамщева Е.Л. Договор подряда в гражданском праве России: дисс. ...канд. юрид. наук. Волгоград. 2005.160 c.

12. Ланг П.П. Правила тонкой капитализации Налогового кодекса Российской Федерации // Юриспруденция в современном мире: проблемы и перспективы: сборник научных трудов подготовленный по материалам общероссийской научно-практической конференции, Тамбов, 15 января 2015 года.- Тамбов: Тамбовский филиал Негосударственного образовательного частного учреждения высшего профессионального образования «Академический правовой институт», 2015. С. 130-133.

13. Постановление ФАС Центрального округа от 23.05.2008 по делу № A23-557/07Г-19-70. 